\title{
Long-term experimental management in Swedish mixed oak-rich forests has a positive effect on saproxylic beetles after 10 years
}

\section{Oskar Gran $^{1}$ (D) . Frank Götmark ${ }^{1}$}

Received: 16 August 2018 / Revised: 18 February 2019 / Accepted: 11 March 2019 /

Published online: 15 March 2019

(C) The Author(s) 2019

\begin{abstract}
Secondary succession in protected oak-rich temperate forests reduces variation in habitats and leads to denser, shadier sites. Long-term experimental studies of the effects of conservation management alternatives are needed for such forests. Here we present a rare followup study of the response of beetles (a highly diverse taxon with many red listed species) to conservation thinning, an action that could favour biodiversity. We previously harvested about $25 \%$ of the tree and shrub basal area in a treatment plot, and no trees and shrubs in a nearby matched minimal intervention plot, in each of eight oak-rich (Quercus robur and/or petrea) forest reserves. After two seasons, thinning had led to an increased number of species of both herbivorous and saproxylic beetles. In the present study, we examined the 10-year response of the beetle groups at the same sites. For herbivorous beetles, the initial positive effect of thinning on the number of species had disappeared after 10 years, presumably because of regrowth. In contrast, saproxylic beetles showed a further positive response after 10 years, increasing in the number of species by a third compared to before thinning. We found no change in species composition of either group due to the thinning, but many saproxylics were unique to thinning plots. Overall, our results suggest that in mixed oak-rich forests, saproxylic beetles seem to benefit from conservation-oriented thinning for at least 10 years.
\end{abstract}

Keywords Canopy openness · Community $\cdot$ Dead wood $\cdot$ Forest succession $\cdot$ Harvest · Insect biodiversity

Communicated by Eckehard G. Brockerhoff.

Electronic supplementary material The online version of this article (https://doi.org/10.1007/s1053 1-019-01736-5) contains supplementary material, which is available to authorized users.

Oskar Gran

oskar.gran@bioenv.gu.se

1 Department of Biological and Environmental Sciences, University of Gothenburg, Box 463, 40530 Gothenburg, Sweden 


\section{Introduction and objectives}

Globally, forests protected for biodiversity and related conservation values have increased; although 'primary forest' decreased, the total global protected forest area increased from $7.7 \%$ in 1990 to $16.3 \%$ in 2015 (Morales-Hidalgo et al. 2015). Given many threats to biodiversity in (non-protected) forests and tree plantations, the protected forests (hereafter, 'reserves') are especially valuable for conservation. In the future, the management of reserves requires more scientific study, for two reasons. Firstly, many forest reserves are not 'primary forest', but stands of secondary succession after former low-impact human land use (e.g. selection cutting, woodland grazing and other forms of older agriculture). Knowledge of the significance of successional change for organism groups in the reserves is important for habitat management decisions. Secondly, the scientific and management communities pay little attention to research within 'strict' forest reserves, even though they are potentially very useful for long-term research (see Götmark et al. 2015). Decisions on habitat management are usually taken by reserve staff based on own experiences (Pullin et al. 2004; Cook et al. 2010) or on general advice from researchers; however, long-term, controlled experiments are needed to clarify potentially misleading short-term effects (Tilman 1987) and the management options available (Davies et al. 2008; Götmark 2013). With long-term results, the advice from research will be more reliable-this is especially true for forests, which develop slowly.

The Swedish Oak Project aims to test habitat management alternatives for temperate closed-canopy oak-rich forest reserves, using a strong replicated Before-After ControlImpact experimental design (see e.g. Götmark 2007; Økland et al. 2008; Rancka et al. 2015). Oak-rich forests and oak woodlands, especially sites with large oaks, support large numbers of associated species, including plants, animals, and fungi of conservation concern (e.g. Paltto et al. 2006; Ranius et al. 2008; Tyler 2008; Sverdrup-Thygeson et al. 2010; Bouget et al. 2013). In many mixed temperate forest reserves in the northern hemisphere, oaks (Quercus spp.) are disfavoured due to increased competition from shade-tolerant tree species, and ungulate browsing. These reserves may develop into mixed old-growth (minimal intervention) forests which in time could produce gaps and semi-open stands (Peterken 2001); alternatively, active management may be tested for oaks and their associated organisms (Brudvig et al. 2011; Nordén et al. 2012; Sebek et al. 2015). Studies of active management, both traditional and non-traditional, combined with matched minimal intervention references, are needed (reviewed by Götmark 2013).

Here we use beetles (Insecta: Coleoptera) to test a form of non-traditional management (conservation-oriented thinning, below 'thinning') against minimal intervention in oak-rich Swedish forest reserves. Beetles are a highly diverse taxon [4712 species in Sweden, out of which 854 are on the Swedish red list (The Swedish Species Information Centre 2018)], and beetles have become very useful in conservation science (e.g. Hammond et al. 2001; Grove 2002; Davies et al. 2008; Hjältén et al. 2012; Jonsell 2012; Bouget et al. 2014). We focus on saproxylic beetle species associated with oak, which in Sweden is the tree genus with the most species-rich saproxylic beetle fauna both in terms of the total number of species $(494$, or $52 \%$ of all saproxylic beetle species) and red listed species (233, or $59 \%$ of all red listed saproxylic beetle species) (The Swedish Species Information Centre 2018). Some red listed beetles occur almost exclusively in old hollow oaks in semi-open pastures, a habitat type usually managed and kept open by grazing livestock (Ranius and Jansson 2000; Ranius et al. 2008). However, most of the forest reserves where oaks occur in Sweden, including more than 30,000 woodland key habitats (Timonen et al. 2010; personal 
dataset from the Swedish Forest Agency), are not grazed by livestock but managed either by minimal intervention, or occasionally partial cutting to favour large oaks and biodiversity (based on advice from Swedish Forest Agency personnel, forest conservation consultants, and others). Some of this very specialized oak fauna is unlikely to colonize the sites we study within the near future (Franc and Götmark 2008; Sverdrup-Thygeson et al. 2010), but even mid-aged oaks and scattered oaks in closed forests harbour a high diversity of beetles (Widerberg et al. 2018).

Here we also investigate herbivorous beetles, a less commonly studied group than saproxylic beetles in conservation science, but potentially affected by thinning through e.g. an increase in the amount and diversity of herbaceous plants (Götmark et al. 2005).

We have earlier reported the short-term response of beetles to thinning, where the mean local number of species of oak-associated saproxylic beetles, and of herbivorous beetles, increased by $35 \%$ on thinning plots as compared to minimal intervention plots (see Franc and Götmark 2008). No effect was seen on the number of red listed saproxylic beetle species, while species composition within the groups changed, though not strongly. These experimental results are important, but does the short-term (2-year) response of beetles last? After ten summer seasons, while there was little change in the minimal intervention plots, the regrowth of shrubs and trees in the understory of the thinning plots was substantial (Leonardsson 2015; Leonardsson et al. 2015). Since it is commonly thought that semi-open, partly sunlit conditions around oaks and dead wood benefit many species of beetles (e.g. Jonsell et al. 1998; Lindhe et al. 2005; Bouget et al. 2014), we hypothesized that due to regrowth the number of species and the species composition of beetles (oak saproxylics, red listed saproxylics, and herbivores) would not differ between thinning and minimal intervention plots 10 years after the thinning. We were interested both in the effect of the thinning on a local, by-site scale, and on all sites combined. Furthermore, to complement our experiment, we examined local environmental factors potentially important for the studied beetle groups.

\section{Methods}

\section{Study sites and experimental treatment}

Our study sites are situated in the cold temperate zone in southern Sweden. In the Franc and Götmark (2008) study, 22 of the 25 sites in the Swedish Oak Project were used. Due to limited resources, we repeated the present 10-year follow-up at eight of the 25 sites, selected to represent the full range of regrowth conditions among the sites, and well distributed over the geographical area used in the project (see Fig. 1). The bedrock consists of granite at four of the sites (Fröåsa, Fårbo, Norra Vi, Ytterhult), gneiss at two of the sites (Rya åsar, Sandviksås) and limestone at two of the sites (Vickleby, Albrunna) (Geological Survey of Sweden 2018). Mean yearly temperature for the sites was $6-7{ }^{\circ} \mathrm{C}$ and mean yearly precipitation about 700-1000 mm during the current standard normal period 1961-1990. During the three months that beetles were sampled (May-July 2013) the mean temperature in the area was $15{ }^{\circ} \mathrm{C}$ and mean monthly precipitation was $65 \mathrm{~mm}$ (Swedish Meteorological and Hydrological Institute 2014).

At each site, two similar one-hectare plots were chosen in 2000, 15-150 m apart. One plot was randomly selected for thinning, and one for minimal intervention. All plots had a history of livestock grazing in wood pasture, in some cases combined with small arable 


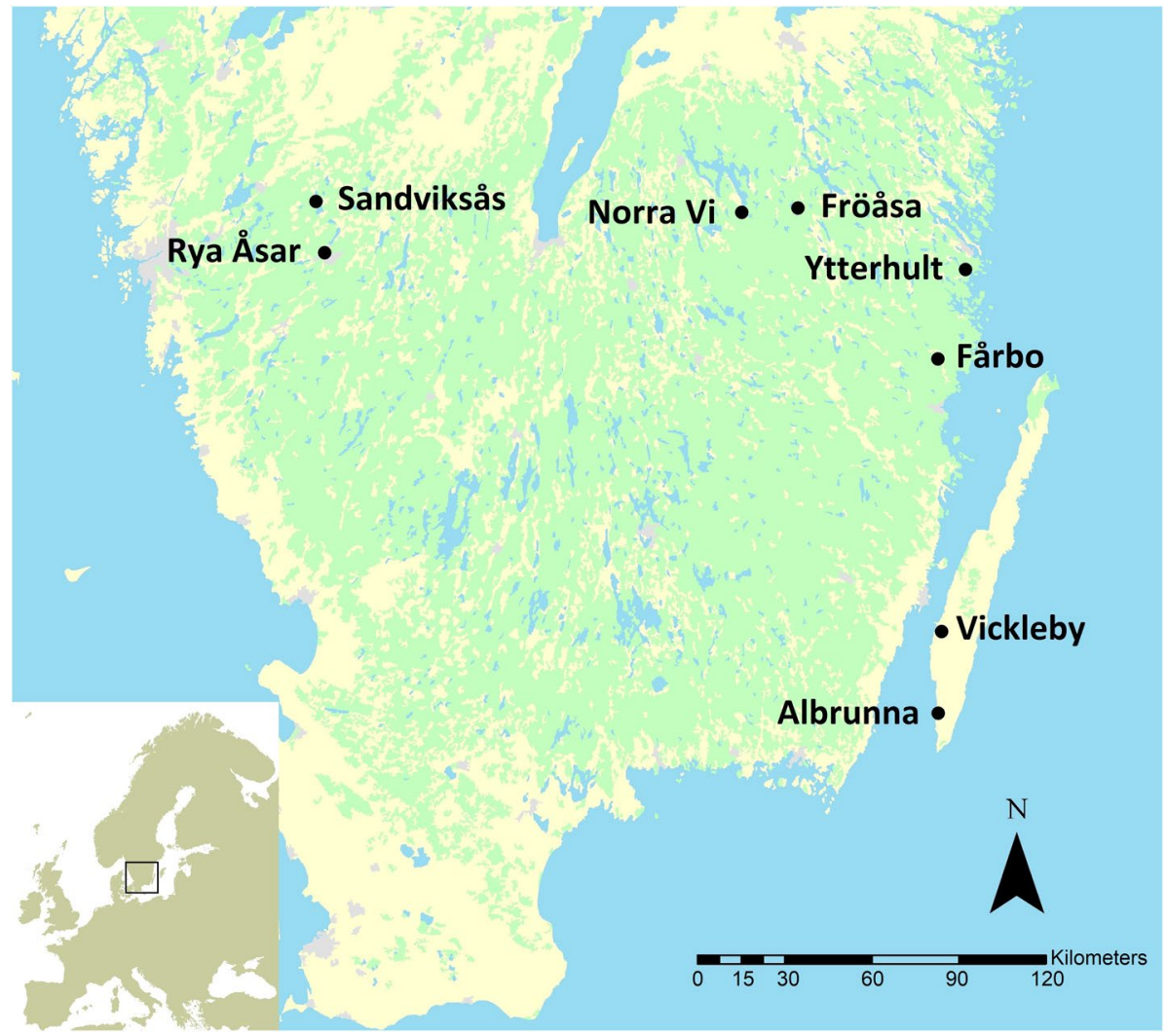

Fig. 1 Map of southern Sweden with the eight study sites marked. Green is forest-dominated land, yellow partly or mainly agricultural areas

fields, but were tall, closed-canopy forest in 2000. The sites were either nature reserves or woodland key habitats (sites with high biodiversity values, identified by the Swedish Forest Agency; Timonen et al. 2010). The dominant large trees on all plots were oaks (Quercus robur and/or $Q$. petraea) and their mean proportion of total tree basal area was about $50 \%$, followed primarily by Picea abies, Betula pubescens and/or B. pendula, Populus tremula, and Fraxinus excelsior in this order. Saplings of these other species, and especially of Corylus avellana or Frangula alnus dominated the understory. Thinning was conducted in the winter of 2002/2003, designed to benefit large oaks (and other large trees of conservation value), to promote regeneration of oak by removing e.g. Betula, conifers and other trees and shrubs, and to test responses of selected taxa. The felled tree trunks were removed from the plots to be used as biofuel, but all previously existing dead wood was left, and additional dead wood was created in the thinning plots by leaving the tops and branches of large trees felled in the thinning. Additionally, two oak logs were created and left in each plot (including minimal intervention) for long-term study. These oaks were subcanopy trees, and felling did not influence canopy openness in minimal intervention plots (the logs were a small fraction of all dead wood of oak). The mean canopy openness (percent sky visible from the ground) in the eight thinned plots increased from $16 \%$ before the thinning to $38 \%$ after the thinning. The mean proportion of the total basal area 
[trees and shrubs $>5 \mathrm{~cm}$ diameter at breast height $(=1.3 \mathrm{~m})$ ] removed per thinning plot was $25.2 \%$ on the eight sites used in this study. For more detailed information on sites, thinning, and canopy openness, see Götmark (2007) and Franc and Götmark (2008).

In 2009, we re-measured canopy openness in the eight thinning plots, using the same methods; it had then decreased to a mean value of $27 \%$. Four more years of regrowth before the present study reduced this value to probably below 20\% (no plot-level data available; trap-level data used below). Figure 2 shows typical regrowth of shrubs and trees for one of the thinning plots between 2002 and 2013. For reference plots, the vegetation was practically unchanged over the years (see also TSOP 2018).

\section{Sampling of beetles and environmental factors}

Franc and Götmark (2008) sampled beetles in both plot types in 2001 before thinning, and again in 2004, 1.5 years (two summer seasons) after thinning at the 22 sites. Sampling in the present study in 2013 was designed to replicate their sampling on two dead standing oaks per plot as closely as possible.

We used the same flight interception window traps as in the previous study, placed on trunks of standing dead oaks, to sample beetles. The traps consisted of $0.2 \times 0.3 \mathrm{~m}$ clear plastic panes, attached vertically on oak trunks at a height of 1.5-3 $\mathrm{m}$ (facing south), and beneath these a white plastic tub containing a glycol and saltwater mixture (see Fig. 2 in
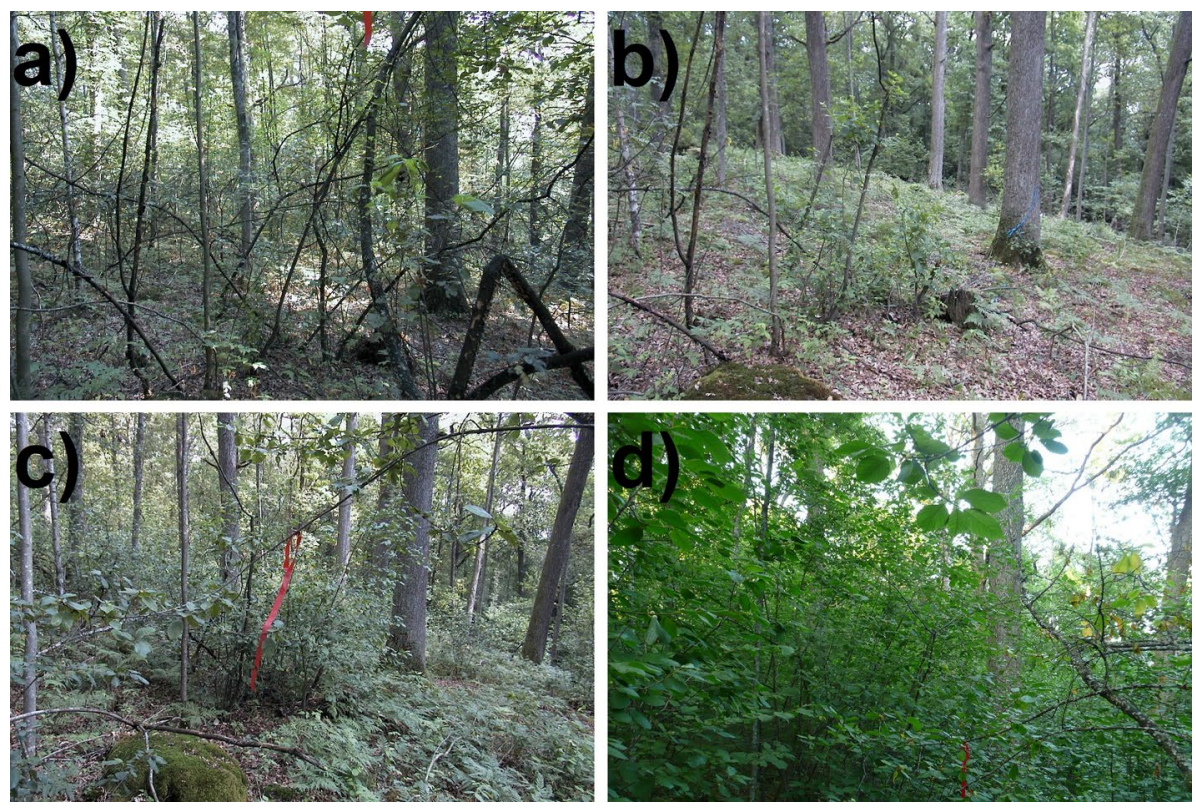

Fig. 2 Photo series showing thinning followed by regrowth on one of our thinning plots, in Rya åsar. All photos taken at the same time of year, from the same spot. a 2002, the summer before the thinning, b 2003, the summer after the thinning, c 2006, three years after the thinning, d 2013, ten years after the thinning. Within thinning plots, the degree of openness varied in space after thinning (some trees and shrubs were desirable to leave, others less desirable). The vegetation was practically unchanged in reference plots over the years 
Franc et al. 2007). As the beetles fly or walk into the pane, they may fall into the tub where they are killed and preserved.

On each plot (thinning and minimal intervention), we selected one recently ( $<\sim 2$ years) dead and one older ( $>\sim 5$ years) dead oak trunk, and put up one trap on each. The selected trunks lacked visible polypores and were not close to the edge of the plots. At five sites (Albrunna, Fröåsa, Fårbo, Rya åsar, Sandviksås), a lack of recently dead oaks necessitated the girdling of a dying tree (or a tree in poor condition) for one of the traps. In these cases, we girdled a dying or poor oak in both the thinning and the minimal intervention plot to make the comparison balanced (a method also used in the previous study). In total, 32 traps were used (two traps on each plot, two plots on each site, eight sites). We set up the traps 6-8 May 2013, emptied them once in mid-June, and emptied and took them down 22-24 July the same year (in 2001 and 2004 the traps were out longer; in the current analyses, data from the third period of the previous years were excluded). All beetles were identified to species level, except for three cases where reliable identification was only possible to genus level.

In 2013, the following four environmental variables were measured at each trap: (1) Circumference $(\mathrm{cm})$. On each dead oak with a trap we measured the circumference of the stem at breast height $(=1.3 \mathrm{~m})$. (2) Deadwood $\left(\mathrm{m}^{3}\right)$. Within a $10 \mathrm{~m}$ radius of each trap tree, we measured dead wood with a circumference $\geq 15 \mathrm{~cm}$. This was done for standing dead trees ("snags") and dead wood lying on the ground ("logs"). Due to uncertainty in identification, species of tree was not recorded. The height of the snags was estimated visually, and circumference measured at breast height. Many snags, though not all, were broken. We estimated their volume by the formula for the volume of a cylinder. This was a rough estimate of the actual volume, treating the stem circumference as the same throughout the snag length and not including e.g. branches, but nevertheless indicates the relative snag volumes near traps. Length, and circumference at both ends, was measured for logs. Their volume was estimated using the formula for a conical frustum: $V=\pi h / 3 \times\left(R^{2}+R r+r^{2}\right)$, where $h$ is length, and $\mathrm{R}$ and $\mathrm{r}$ are the radiuses at the ends. For each trap, we pooled the snag and $\log$ volumes. (3) Sky (\%). At each trap tree, we took four photos of the sky from the ground straight up, one at each cardinal direction. The photos were converted to monochrome images and processed to make the open sky (including clouds) all white. They were then analysed for percentage white (sky) and black (canopy) using ImageJ, v.1.47 (Schneider et al. 2012), giving an estimate of canopy openness around each trap. (4) Herbs (\%). At a $10 \mathrm{~m}$ distance from each trap in each cardinal direction, a $1 \times 1 \mathrm{~m}$ square was placed on the ground, making four squares per trap. In the squares, we estimated the percentage ground covered by herbaceous plants in intervals $(0 \%, 5 \%, 10 \%$, etc. $)$, and used the average value for each trap in the analysis.

\section{Data and statistical analyses}

All raw data from 2001 and 2004 was from the study by Franc and Götmark (2008), and was analysed together with the data from the present study, collected in 2013.

We classified beetles into three groups: (1) oak saproxylics, (2) herbivores, and (3) red listed saproxylics. For classification of oak saproxylics, we used Dahlberg and Stokland (2004), The Swedish Species Information Centre (2018), and in a few cases the classification done by Franc and Götmark (2008). The species included in the analysis of 'oak saproxylics' were reported as being both obligate saproxylics and obligately or facultatively associated with oak. Species included in the analysis of 'herbivores' were reported 
as herbivorous in The Swedish Species Information Centre (2018), the classification done by Franc and Götmark (2008), or in four cases Lindroth (1961). In accordance with the classification of Franc and Götmark (2008), we also included among herbivores obligate predators on herbivores in e.g. the family Cantharidae. The species included in the analysis of 'red listed saproxylics' were species reported as obligate saproxylics in the same sources as for the oak saproxylics, and listed on any of the three Swedish red lists from the period covered by the study (The Swedish Species Information Centre 2000, 2005, 2010). We combined the three lists into one for the 3 years we analysed, to allow for better comparison between years. To allow for a larger set of saproxylics to be included, we also added non-oak saproxylics to the analysis of red listed species. The effects of the thinning and of environmental variables on the number of red listed species were not tested statistically as the numbers of individuals and species were too few for meaningful analysis. The per-trap species data are given in Online resource 1.

A measure of the number of species per trap or plot can be said to be a measure of species density (number of species per area, see e.g. Gotelli and Colwell 2001) but for clarity we will refer to this as "number of species" or equivalent, and will limit the use of the term species density to referencing species accumulation curves.

All analyses were done using R v.3.4.3 (R Core Team 2017) unless otherwise explained. We analysed the effect of treatment and of environmental variables on local number of species with a REML linear mixed model (LMM) using the 'Ime4' R package (Bates et al. 2015). The p-values were computed through Satterthwaite approximation using the 'ImerTest' R package (Kuznetsova et al. 2017). This method has Type I error rates closer to 0.05 than other commonly used methods for deriving p-values in LMMs, especially for smaller sample sizes (Luke 2017). To examine the effect of treatment on the local scale, we pooled the data from the two traps on each plot and used the number of species on the thinning plot minus the number of species on its corresponding minimal intervention plot as our dependent variable, resulting in $n=8$ for each of the 3 years and for a total of $n=24$. In seven cases (four in 2004, three in 2013) data was missing from a trap during a period due to the trap falling down. We then removed the same period for the corresponding trap on the opposite plot at the site from the analysis. Year was set as a fixed factor in the LMMs and we used random intercepts for sites, both with difference in number of saproxylic oak species as dependent variable (Model 1 and 2, see below) and with difference in number of herbivore species as dependent variable (Model 3).

We analysed the relationships of environmental variables to local number of species with data per trap (meaning two traps per plot, two plots per site, and eight sites), and only for 2013. In the cases of missing data (two traps), these traps were removed from the analyses, resulting in $n=30$. In the model we used number of oak saproxylic species 2013 as dependent variable (Model 4), circumference, sky, deadwood, and treatment were set as fixed factors, with random intercepts for sites. Plotting suggested that the relationship between number of oak saproxylic species and dead wood volume was best described by a power function, so in accordance with Martikainen et al. (2000) we ln-transformed dead wood volume before analysis. In the model with difference in number of herbivore species 2013 as dependent variable (Model 5), sky, herbs, and treatment were set as fixed factors, once again with random intercepts for sites.

Visual inspection of residual plots did not reveal any major deviations from normality or homoscedasticity in any of the LMMs. We examined multicollinearity by variance inflation factors (VIF), and no values were higher than the 2.0 cut-off suggested by Zuur et al. (2010). The presence of influential outliers in the LMMs was examined with the Cook's distance measure (Cook 1977) calculated using the 'influence.ME' R package 
(Nieuwenhuis et al. 2012). In the analysis of the treatment effect on difference in number of oak saproxylic species, one data point stood out as an outlier with a Cook's distance of 0.50 , with the next highest value being 0.09 . One of the traps in the minimal intervention plot produced the high deviating value, placed on a tree with the largest circumference in the data set and catching high numbers of oak saproxylics and red listed species. We therefore decided to perform the analysis both with (Model 1), and without this outlier (Model 2). Removing the outlier trap and its corresponding trap on the thinning plot from the analysis allowed the sample size to remain the same but brought all Cook's distance values down to a similar size, below 0.15 . There were data points with comparably high Cook's distance values in the other analyses, but none were as clear outliers and we found no reason to believe that they were not a true part of the population being sampled. We decided to use the full dataset in these models.

Total species density and species richness (for a discussion of these terms, see Gotelli and Colwell 2001) in each year-by-treatment combination was compared by species accumulation curves. These were constructed using EstimateS v.9.1.0 (Colwell 2013), which provides both interpolated (rarefaction) and extrapolated (asymptotic estimation) values of species density or richness, and unconditional 95\% confidence intervals for these (Colwell et al. 2012). The confidence intervals are conservative, and overlap does not necessarily indicate non-significant differences at $\alpha=0.05$. We used sample-based abundance data, the "classic formula Chao2" asymptotic estimator, and extrapolated to double the samplesize, i.e. $n=16$. When plotting species richness, we rescaled the $\mathrm{x}$-axis from samples to expected number of individuals, as per Gotelli and Colwell (2001).

Differences in species assemblages were analysed with a PERMANOVA (Anderson 2001) using PRIMER v.7.0.13 (Clarke et al. 2014) with the PERMANOVA+addon (Anderson et al. 2008). We performed the analysis using Bray-Curtis similarity between each pair of plots, calculated from data that had been square-root transformed to reduce the importance of numerically dominant species. We used a repeated-measures ANOVA design for the PERMANOVA with treatment and year as fixed factors and site as a crossed random factor. Because the design lacks replication at the lowest level (i.e. only one thinning and one minimal intervention plot per site), the highest interaction term (site-by-treatment-by-year) had to be excluded from the analysis.

We also produced rank abundance curves to examine evenness and dominance, and Venn diagrams of shared and unique species for the two treatments, for each treatmentby-year combination. All plots were drawn using the 'ggplot2' R package (Wickham 2009), except for Venn diagrams of unique and shared species which were drawn using the 'VennDiagram' R package (Chen 2017). Standard errors used in Figs. 3 and 4 were taken from the mixed model estimates, while for red-listed saproxylics (Fig. 5), within-subject standard error was calculated using the 'Rmisc' R package (Hope 2013), following Morey (2008).

\section{Results}

In 2013, 2802 beetle individuals of 321 species were caught. Of these, 149 species were classified as oak saproxylics, 50 as herbivores, and 23 as red listed saproxylics. The total number of individuals caught in 2001, and included in the analysis, was higher than in 2004, which in turn was higher than in 2013, but the total number of species was highest in 2013 (see Table 1). Among the oak saproxylics in the entire 3-year sample, 60 species were 
(a)
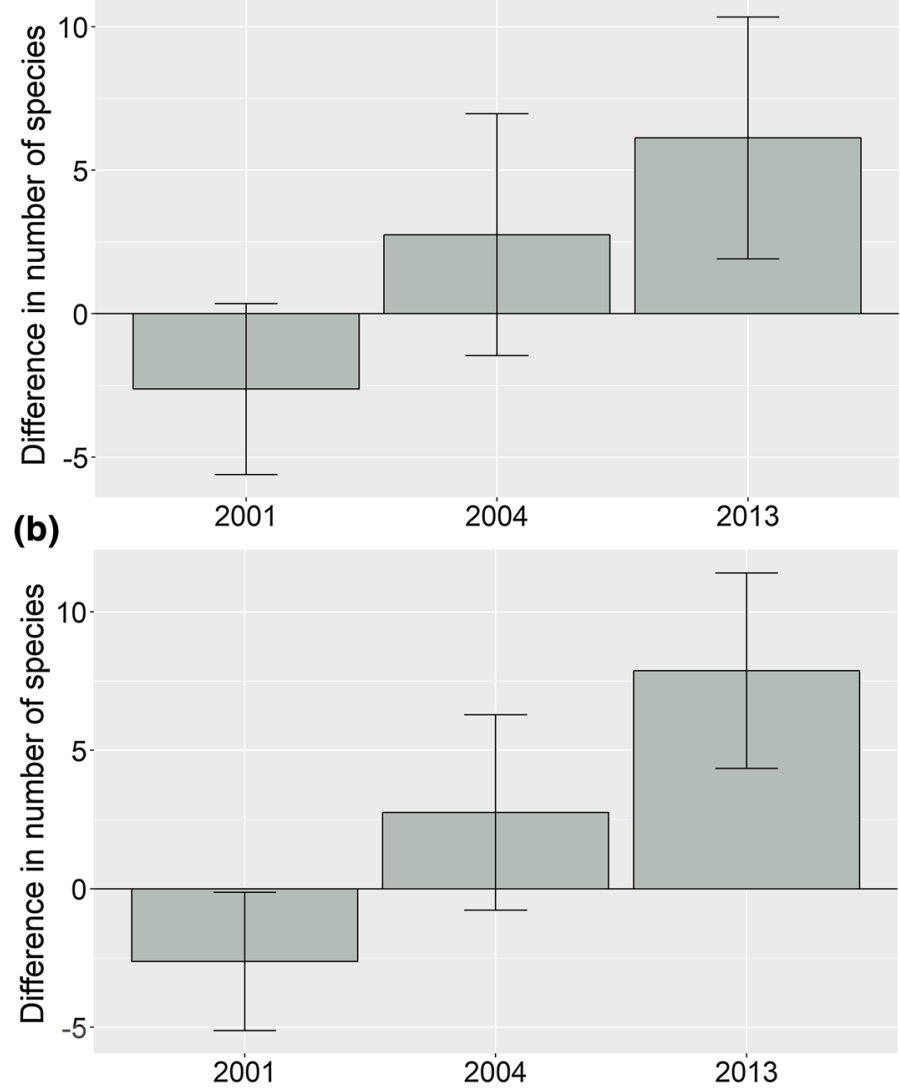

Fig. 3 Number of oak saproxylic species on thinning plots minus number on the corresponding minimal intervention plots for the 3 years, a with, and $\mathbf{b}$ without Vickleby outlier trap and corresponding trap on opposite plot in 2013. Mean values \pm SE

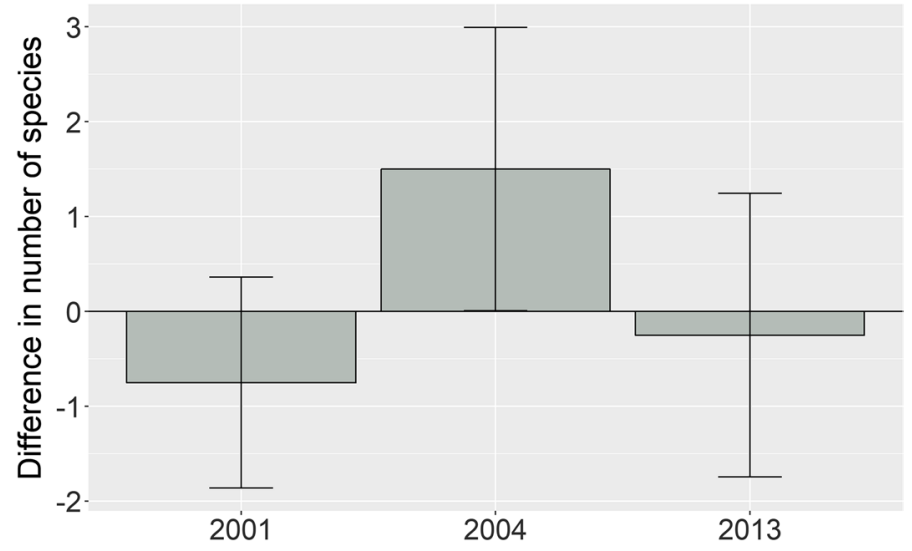

Fig. 4 Number of herbivore species on thinning plots minus number on the corresponding minimal intervention plots for the three years. Mean values \pm SE 


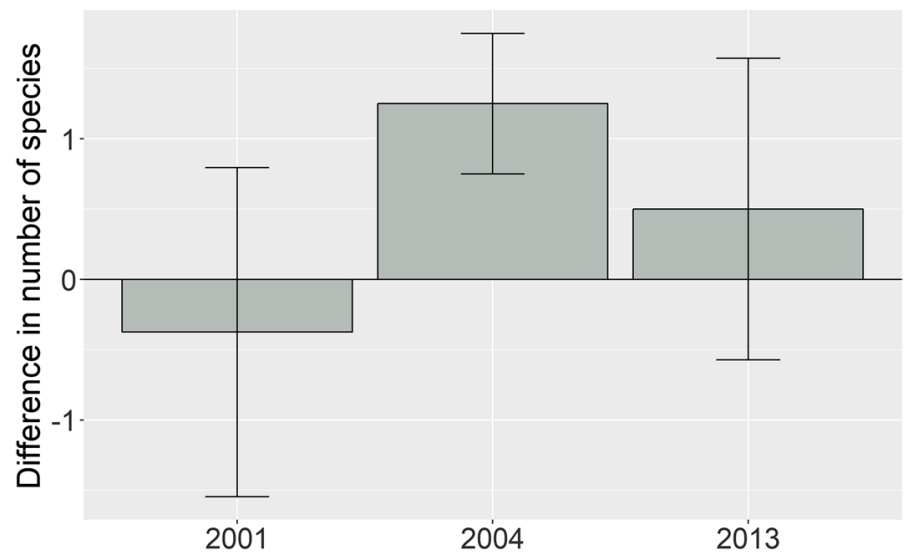

Fig. 5 Number of red listed saproxylic species on the thinning plots minus number on the corresponding minimal intervention plots for the three years. Mean values $\pm \mathrm{SE}$

Table 1 Summary of species and individuals found per treatment, year, and species group

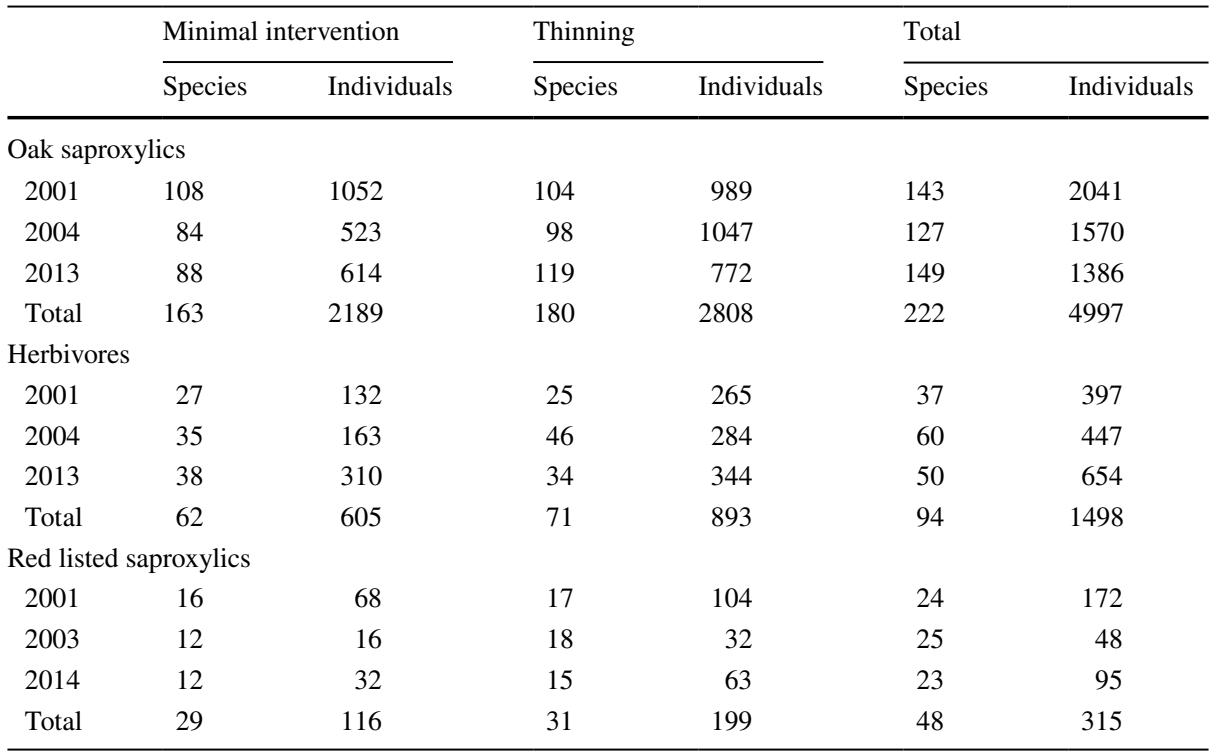

represented by only one individual ('singletons') and 34 species by only two individuals ('doubletons'). For the herbivores, the corresponding numbers were 45 singletons and 12 doubletons.

\section{Experimental effect on local beetle species numbers}

The number of oak saproxylic species on thinning plots, minus the number on minimal intervention plots (from here on 'number of saproxylic species on thinning plots'), increased from 2001 (mean $-2.6 \pm$ SE 3.0) to 2004 (2.8 \pm 4.2 ), and again from 2004 to 
$2013(6.1 \pm 4.2)$ (Fig. 3a). The change in number of oak saproxylics on thinning plots (as controlled for by the change on minimal intervention plots) equalled $+20 \%$ from 2001 to 2004, and $+14 \%$ from 2004 to 2013, for a combined change of $+33 \%$ from 2001 to 2013 . At $\alpha=0.05$, number of saproxylic species on thinning plots was not significantly different from the 2001 starting point in $2004(\mathrm{p}=0.22)$ but was essentially so in $2013(\mathrm{p}=0.0504)$ (Table 2, Model 1). Excluding the outlier trap and its corresponding trap on the other plot meant that mean number of saproxylic species on thinning plots in 2013 increased to $7.9 \pm 3.5$ (Fig. 3b), significantly different from the 2001 starting point $(\mathrm{p}=0.007)$ (Table 2 , Model 2).

The number of herbivore species on thinning plots, minus the number on minimal intervention plots (from here on 'number of herbivore species on thinning plots'), increased from $2001(-0.8 \pm 1.1)$ to $2004(1.5 \pm 1.5)$, and decreased from 2004 to $2013(-0.3 \pm 1.5)$ (Fig. 4). The change in number of herbivore species on thinning plots (as controlled for by the change on minimal intervention plots) equalled $+40 \%$ from 2001 to 2004 , and $-18 \%$ from 2004 to 2013, for a combined change of $+9 \%$ from 2001 to 2013. Number of herbivore species on thinning plots was not significantly different from the 2001 starting point in $2004(\mathrm{p}=0.15)$ or $2013(\mathrm{p}=0.74)$ (Table 2, Model 3).

The number of red listed saproxylic species on thinning plots, minus the number on minimal intervention plots, increased slightly from $2001(-0.4 \pm 1.2)$ to $2004(1.3 \pm 0.5)$

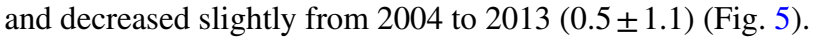

\section{Relationship of environmental variables to local number of species}

Among the environmental factors included in our model, only canopy openness ('sky') had a significant effect on local number of oak saproxylic species $(\beta=0.235 ; \mathrm{p}=0.0007)$

Table 2 Statistics for the linear mixed models of the treatment effect on the number of oak saproxylic species (Model 1 and Model 2) and herbivore species (Model 3)

\begin{tabular}{|c|c|c|c|c|c|c|}
\hline \multicolumn{5}{|c|}{ Fixed effects } & \multicolumn{2}{|c|}{ Random effects } \\
\hline Factor & Estimate & SE & df & $\mathrm{p}$ & Factor & SD \\
\hline \multicolumn{7}{|c|}{ Model 1: Diff. in number of oak saproxylic species $\sim$ year $+(1$ site $)$} \\
\hline Intercept & -2.625 & 2.980 & 21.000 & 0.388 & Site & 0.000 \\
\hline 2004 & 5.375 & 4.215 & 21.000 & 0.216 & Residual & 8.430 \\
\hline 2013 & 8.750 & 4.215 & 21.000 & 0.050 & & \\
\hline \multicolumn{7}{|c|}{ Model 2: Diff. in number of oak saproxylic species $\sim$ year + (1lsite $)$} \\
\hline Intercept & -2.625 & 2.493 & 21.000 & 0.304 & Site & 0.000 \\
\hline 2004 & 5.375 & 3.526 & 21.000 & 0.142 & Residual & 7.052 \\
\hline 2013 & 10.500 & 3.526 & 21.000 & 0.007 & & \\
\hline \multicolumn{7}{|c|}{ Model 3: Diff. in number of oak saproxylic species $\sim$ year $+(1$ site $)$} \\
\hline Intercept & -0.750 & 0.110 & 20.634 & 0.507 & Site & 0.964 \\
\hline 2004 & 2.250 & 1.494 & 14.000 & 0.154 & Residual & 2.998 \\
\hline 2013 & 0.500 & 1.494 & 14.000 & 0.743 & & \\
\hline
\end{tabular}

The dependent variable in all three models is the number of species on thinning plots minus the number of species on the corresponding minimal intervention plots $(n=24)$. In Model 2, one 2013 outlier trap and its corresponding trap on the opposite plot have been removed from the analysis, otherwise it is identical to Model 1. Significant p-values at $\alpha=0.05$ indicated in bold text 
Table 3 Statistics for the linear mixed models of the effect of environmental variables on the number of oak saproxylic species (Model 4) and herbivore species (Model 5) in 2013

\section{Fixed effects}

\begin{tabular}{lllllllllll}
\hline Factor & Estimate & $\mathrm{SE}$ & $\mathrm{df}$ & $\mathrm{p}$ & & Factor & $\mathrm{SD}$ \\
\hline
\end{tabular}

Model 4: Number of oak saproxylic cycles $2013 \sim$ sky + circumference $+\operatorname{In}($ deadwood $)+$ treatment $+(1$ lsite $)$

$\begin{array}{lrrrrll}\text { Sky } & 0.235 & 0.060 & 22.160 & \mathbf{0 . 0 0 1} & \text { Site } & 4.757 \\ \text { Circumference } & 0.045 & 0.023 & 21.778 & 0.059 & \text { Residual } & 4.229 \\ \text { In(Deadwood) } & -0.206 & 1.056 & 22.922 & 0.847 & & \\ \text { Thinning } & 0.415 & 1.668 & 18.327 & 0.806 & & \end{array}$

Model 5: Number of herbivore species 2013 sky + herbs + treatment $+(1$ site $)$

\begin{tabular}{lrrrrll} 
Sky & 0.024 & 0.027 & 24.772 & 0.374 & Site & 1.323 \\
Herbs & 0.040 & 0.021 & 23.337 & 0.078 & Residual & 1.879 \\
Thinning & -1.421 & 0.778 & 19.761 & 0.083 & & \\
\hline
\end{tabular}

The dependent variable in both models is number of species per trap $(\mathrm{n}=30)$. Significant $\mathrm{p}$-values at $\alpha=0.05$ indicated in bold text
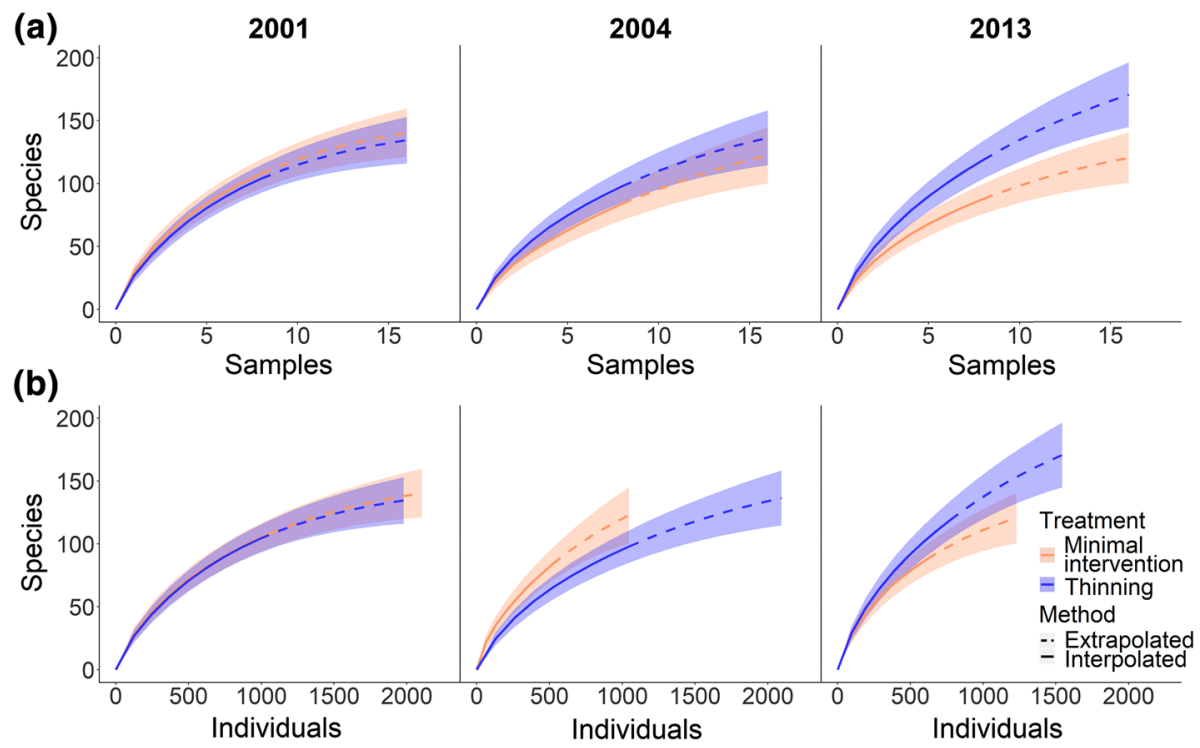

Fig. 6 Species accumulation curves with $95 \%$ unconditional confidence intervals for oak saproxylics over the 3 years. a showing species density, and b showing species richness, with the x-axis rescaled from samples to individuals. The curves have been extrapolated to twice the sample size $(n=16)$

(Table 3, Model 4). None of the environmental factors had a significant effect on the local number of herbivore species (Table 3, Model 5).

\section{Experimental effect on total species density and species richness}

Species density accumulation curves for oak saproxylics (Fig. 6a) were almost identical between thinning and minimal intervention plots in 2001 but diverged after the thinning 
in 2004 with the thinning plots higher, although with overlapping confidence intervals. In 2013, the curves were clearly diverging with the thinning plots higher, and the confidence intervals no longer overlapping. The species richness curves for oak saproxylics (Fig. 6b) also started out nearly identical in 2001, but in 2004 the curve for the thinning plots had dropped down below the minimal intervention curve, indicating that the higher number of individuals (relative to the minimal intervention plots) after thinning was not accompanied by a correspondingly higher number of species. In 2013, this pattern was reversed, with the curves diverging but with thinning plots now higher, indicating an increase in total species richness of oak saproxylics 10 years after the thinning, as compared to the minimal intervention plots.

For the herbivore species, the species density curve (Fig. 7a) for the thinning plots started out similar to the minimal intervention plots in 2001, rose slightly above it after the thinning in 2004 (still with substantial overlap of confidence intervals), and dropped down again in 2013. The pattern in the species richness curves for herbivores (Fig. 7b) was similar, but an uneven number of individuals between the treatment types already in 2001 made interpretation less straightforward.

\section{Experimental effect on species composition}

The treatment-by-year interaction was not significant in the PERMANOVA on either oak saproxylics $(F=1.05 ; p=0.42 ; 9881$ permutations $)$ or herbivores $(F=0.82 ; p=0.67 ; 9930$ permutations), indicating no major effect of the thinning on species composition of either group.
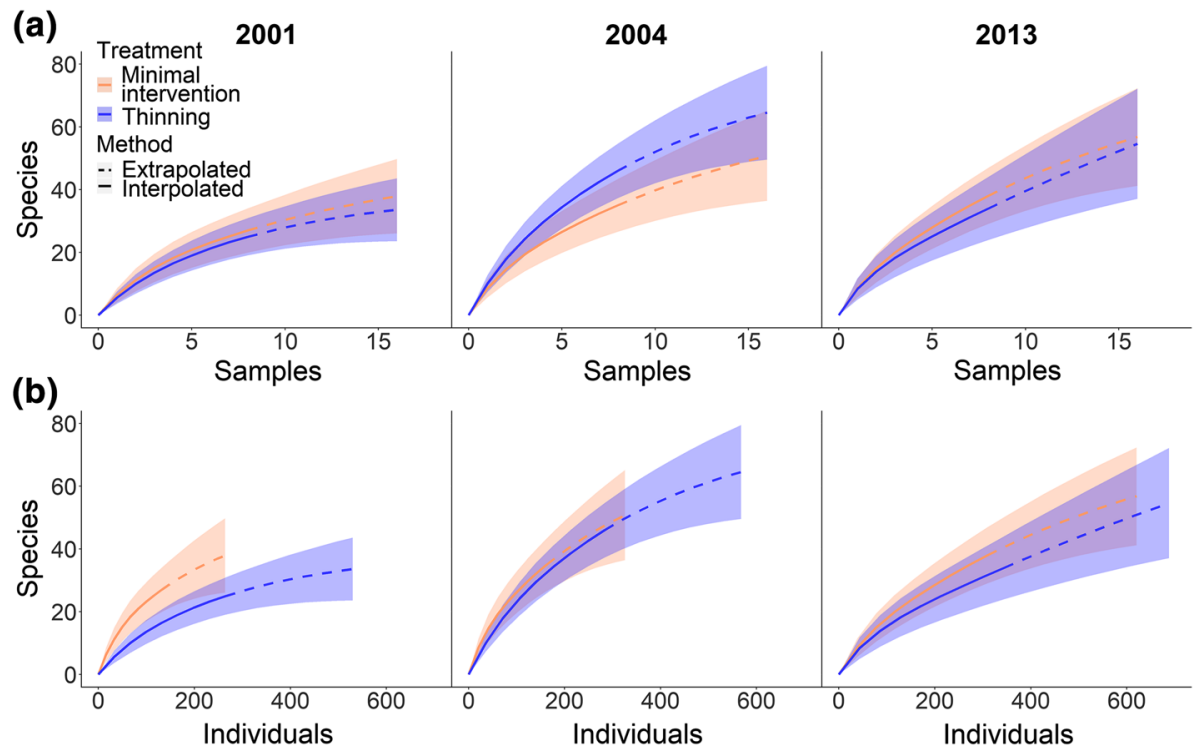

Fig. 7 Species accumulation curves with 95\% unconditional confidence intervals for herbivores over the 3 years. a showing species density, and b showing species richness, with the $\mathrm{x}$-axis rescaled from samples to individuals. The curves have been extrapolated to twice the sample size $(n=16)$ 


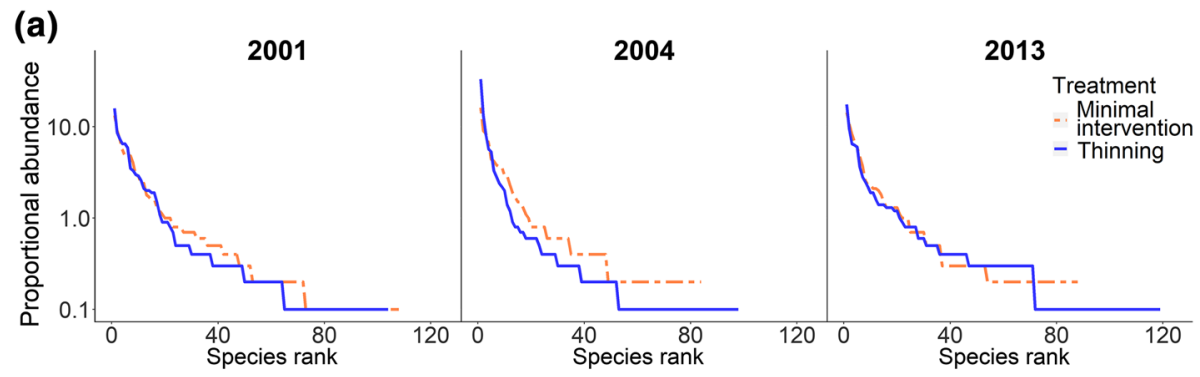

(b)

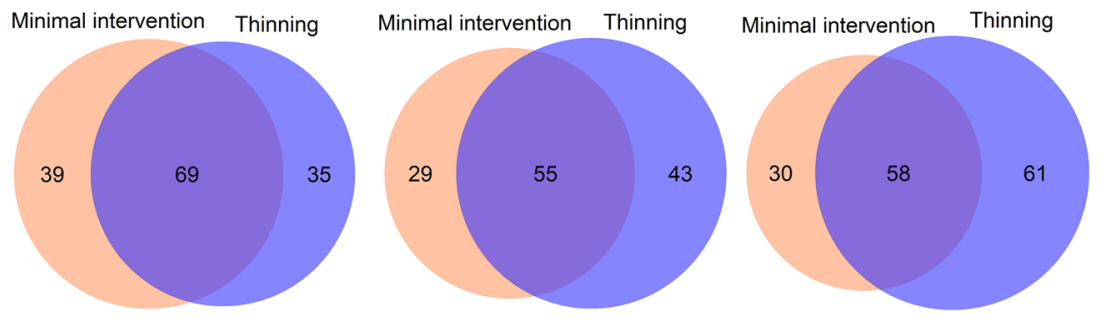

Fig. 8 a Rank abundance curves, and $\mathbf{b}$ Venn diagrams of the number of species unique to one or the other treatment type or shared between them, for oak saproxylics over the 3 years

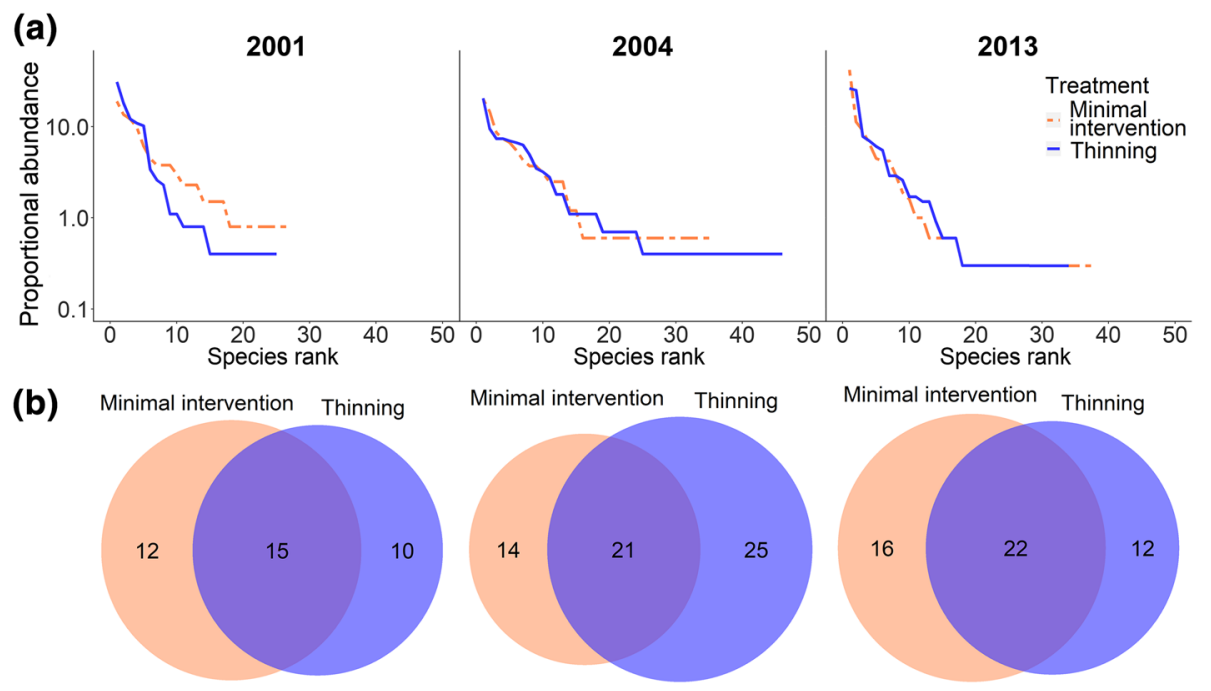

Fig. 9 a Rank abundance curves, and b Venn diagrams of the number of species unique to one or the other treatment type or shared between them, for herbivores over the 3 years

Rank abundance curves for oak saproxylics showed a slightly steeper slope for the thinning plots in 2004 compared to the minimal intervention plots, indicating reduced evenness of the species composition right after thinning (Fig. 8a). No such patterns could be seen in the other years, or for herbivores (Fig. 9a).

There was a marked increase in the number of oak saproxylic species found only on the thinning plots from 2001 to 2004 and again from 2004 to 2013 (Fig. 8b). The same was 
true of herbivore species from 2001 to 2004, but the number dropped back down again from 2004 to 2013 (Fig. 9b).

\section{Discussion}

Our results clarify both short- and long-term responses of beetles to active, non-traditional management in mixed oak-rich forests. We find relatively long-lasting, positive effects of conservation thinning on oak-associated saproxylic beetles ('oak saproxylics'), a group of high conservation concern (Stokland et al. 2012; Cálix et al. 2018).

\section{The effect of conservation thinning on oak saproxylic beetle species numbers}

In our previous study, we found a short-term positive effect of thinning on oak saproxylics (Franc and Götmark 2008), which may be caused by increased openness. Although the effect of canopy openness on the diversity of saproxylic beetles living on other tree species seems to be less clear (e.g. Similä et al. 2002; Svedrup-Thygeson and Ims 2002; Jonsell et al. 2004), studies in oak forests generally conclude that the diversity increases as stands become more open (e.g. Ranius and Jansson 2000; Warriner et al. 2002; Widerberg et al. 2012, Bouget et al. 2013). However, studies of the effect of experimental cutting on saproxylic beetles have mainly focused on the first few years after treatment (e.g. Newell and King 2009; MacLean et al. 2015). In Finland, the positive effect of partial cutting on saproxylic beetles in coniferous forests disappeared after 2 years (Toivanen and Kotiaho 2010). In the present study, we found a further increase in the number of species of oak saproxylics on thinning plots, controlling for change on minimal intervention plots, from 2004 to 2013, 10 years after the thinning.

Bouget et al. (2013) suggested that a positive effect of canopy openness on the diversity of saproxylic beetle species may be mainly due to three factors: (i) an increase in nearby flowering plants in combination with deadwood, benefiting saproxylics whose adults visit flowers; (ii) higher levels of activity of insects in sunnier, warmer conditions, leading to increased numbers of individuals and therefor species caught, relative to more closed-canopy areas; and (iii) an increase in the amount of suitable open habitat substrate (such as sun-exposed dead wood and fungi), preferred and colonized by many saproxylic beetles.

If the first factor (i) was the main cause of the continued high or increasing number of oak saproxylic species after thinning, we would presumably see a similar pattern among herbivorous beetles ('herbivores'). However, although the increase in the number of oak saproxylic species and herbivore species from 2001 to 2004 was similar, the latter decreased from 2004 to 2013, while oak saproxylics continued to increase. Thus, availability of flowering plants in proximity to dead wood was probably not a main factor in the long-term increase in the number of oak saproxylic species.

The second factor (ii) is an objection commonly raised against the use of flight interception traps to compare diversity of insects between habitats that differ in canopy openness. However, a study on the number of saproxylic beetles caught by flight interception traps (catching beetles that move around in the area) and by emergence traps (catching all beetles that emerge from pieces of wood) in sunny and shady stands found no difference (Wikars et al. 2005). This indicates that the potential "activity effect" may not be a major factor influencing estimated number of beetle species. Furthermore, although the degree of canopy openness around the traps had a significant positive effect on the number of 
oak saproxylic species, the same was not true for herbivores, and we have no reason to believe that the activity effect would vary between functional groups of beetles. Lastly, the increased number of oak saproxylic species in our study was evident in species accumulation curves plotted with both species density and species richness. An increased number of individuals caught on the thinning plots should not affect the comparison using the species richness curves, as these are compared at an equal number of individuals. All in all, we conclude that factor (ii) does not seem to be a major cause of the observed effect.

Increased number of oak saproxylic beetle species after thinning may be mainly due to factor (iii), i.e. an increase in suitable substrates, both through increased sun-exposure and by addition of new dead wood. If addition of dead wood during thinning (e.g. branches left, stumps created) contributed to increased number of species, it is possible that this effect does not disappear within 10 years, as dead oak decays slowly. While different decay stages of dead wood contain different saproxylic faunas (Jonsell et al. 1998), among red listed saproxylics the largest number of species are associated with decaying wood 5 to 15 years old, and the lowest number of species with wood under 2 years (Jonsell et al. 1998; Lassauce et al. 2012). Although creation of dead wood in coniferous forests may have a positive effect on saproxylic beetle diversity, the effect can be short-lived ( $<5$ years) (Komonen et al. 2014). Unlike conifers however, large oaks also create much dead wood when they are alive (Nordén et al. 2004) and there was a continuous supply of sun-exposed, old and fresh oak dead wood on the thinning plots (personal observation).

The increased number of oak saproxylic species from 2004 to 2013 was not our expectation. While the thinning plots had a more closed understory in 2013 than in 2004, the degree of regrowth varied among and within sites, and thinning plots were still more open on average than minimal intervention plots (Leonardsson 2015; Leonardsson et al. 2015). The degree of openness required to maintain a rich "open-habitat" saproxylic fauna may not be very high, and the accumulation of common saproxylic species in oak stands may decrease above 17\% openness (Bouget et al. 2013). Alexander (1999) reported the largest number of saproxylics on oak in intermediate openness, although Bouget (2014) found a threshold at $40 \%$, similar to the degree of openness on our thinning plots right after thinning but considerably higher than the degree of openness 10 years later. However, although the understory has regrown, the same is not true for the oak canopies, which may provide important habitat for saproxylic beetles (Bouget et al. 2011). Another possible explanation for the continued increase in the number of oak saproxylic species is a delay in the effect of the thinning, with beetles colonizing over time, or e.g. saproxylic fungal diversity and complex fungus-beetle interactions increasing over the years.

In the earlier Franc and Götmark (2008) study, with 14 more sites included $(n=22)$, the size of the thinning effect was larger (35\% increase in local number of oak saproxylic species from 2001 to 2004) compared to the present study where eight of the sites were used (a 20\% increase over the same period). This suggests that the positive effect of thinning on oak saproxylics reported here may be an underestimation.

Looking at the species accumulation curves of oak saproxylics in 2004, the pattern in the density curves and the richness curves contrasted, with the former showing an increase in species density after thinning, in line with the results in Franc and Götmark (2008), but the former showing a decrease in species richness. Species accumulation curves based on richness may be a useful complement to those based on density, especially when analysing the effects of disturbance treatments that may affect the number of individuals as well as the number of species (McCabe and Gotelli 2000; Gotelli and Colwell 2001). There was a sizeable increase in the number of individuals caught on the thinning plots from 2001 to 2004 as compared to the minimal intervention plots, but these consisted largely of a 
few very abundant species (e.g. Dasytes plumbeus, Enicmus rugosus, Scolytus intricatus). The pattern is visible in the rank abundance curves, where the thinning plots have a more steeply downward slope in 2004 , indicating reduced evenness in species composition. A large increase in abundance of a few species will lower the species richness curves, but not the species density curves. In 2013, this boost in abundance after the thinning had subsided, and the pattern in the two sets of curves was similar. This highlights the importance of the choice of diversity measure in comparisons like this, and carefulness in interpreting immediate, potentially short-lived effects of conservation treatments.

Several studies comparing diversity of saproxylic beetles in sun-exposed and closedcanopy habitats omit difficult-to-identify families such as Staphylinidae, Ptiliidae, and Cryptophagidae (e.g. Ranius and Jansson 2000; Bouget et al. 2013). A large portion of the species in these families belong to functional groups such as fungus-feeders that may prefer damp and shady conditions. A focus on the large and charismatic Cerambycidae, Buprestidae, and others, known to prefer sun-exposed habitats (Bouget 2005; Vodka et al. 2009), might lead to an unwarranted emphasis on the importance of openness, although a recent study (Parmain et al. 2015) indicates that the inclusion of Staphylinidae in studies like these may not change the outcome substantially. Regardless, as we examined all saproxylic beetle groups we are confident that our results are representative of the group as a whole.

Our sample contained too few red listed species and individuals for analyses, but we found no sign of decrease in red listed species after thinning. A larger number of red listed species prefer sun-exposed than shady conditions (Jonsell et al. 1998), and the preference for sun-exposure seems to be higher among saproxylics that are red listed than among those that are not (Similä et al. 2002). However, a too drastic increase in canopy openness could possibly negatively affect diversity of red listed saproxylics in the mixed oak-rich forests that we study, by eliminating species that prefer a shadier habitat (Franc and Götmark 2008).

\section{The effect of conservation thinning on herbivorous beetle species numbers}

In contrast to the oak saproxylics, the number of herbivore species reverted back to its original 2001 level after the increase in 2004. In 2003, directly after the thinning, fast growth of herbaceous plants increased their species numbers (Götmark et al. 2005), but this initial growth was subsequently largely replaced by woody plant understory (Leonardsson 2015; Leonardsson et al. 2015). Although several beetle species are herbivorous on bushes such as Corylus avellana, it is possible that the increase in herbivorous species was a response to this initial but temporary herb abundance and diversity. However, the cover of herbaceous plants had no significant effect on the number of herbivore species in our study. The species density accumulation curves showed a similar pattern, while the interpretation of the species richness curves is complicated by substantial differences in number of individuals present already in 2001. In sum, it would seem that conservation thinning is of limited use in promoting a major long-term increase in the number of herbivorous beetle species in deciduous forests, unless partial cutting is repeated quite often.

\section{Species composition and environmental factors}

The thinned and minimal intervention plots had partly different oak saproxylic faunas in 2004 (Franc and Götmark 2008); others report similar results for oak forests (Bouget 2005; 
Vandekerkhove et al. 2016), and for other deciduous trees (Svedrup-Thygeson and Ims 2002). However, 10 years later species composition of oak saproxylics and of herbivores did not differ between plot types. Our eight sites are situated over a relatively large and varied biogeographic area, with apparently large differences in species composition between sites and years, while thinning and minimal intervention plots within sites were close, with no dispersal barriers between them.

The number of species unique to the thinning plots increased over the years, and in 2013 there were more species unique to the thinning plots than shared between the plot types. Many of the species unique to one or the other treatment were singleton or doubleton species. This pattern may primarily reflect the overall enrichment of the thinning plots, rather than the increased presence of a truly specialized "thinning plot fauna".

The relationship between local dead wood and local number of saproxylic beetle species seems unclear, and although Martikainen et al. (2000) reported a positive relationship, other authors found no, or only small or negligible trends (Brin et al. 2009; Lassauce et al. 2011; Bouget et al. 2013). The degree of canopy openness around the traps was the only variable with a significant effect in our study, with an estimated increase of 0.235 oak saproxylic species per $1 \%$ increase in canopy openness. This is consistent with the effect of the thinning on the number of species and reaffirms the importance of openness for oak saproxylics.

\section{Conclusions and implications}

Three points are relevant. Firstly, despite regrowth of woody plants in our oak-rich forests, a single conservation thinning had a long-lasting positive effect on saproxylic oak beetles, a species-rich taxon of interest to conservation science and practical management. Secondly, forests develop slowly, and Tilman's (1987) advice of running experiments for at least 30 years is wise; for instance, how often should conservation thinning be performed to maintain the observed benefit for saproxylic oak beetles? Or alternatively, would oldgrowth gap dynamics in time make our minimal intervention plots semi-open with more dead wood, partly eliminating the need for such active management? A 'wait-for-succession/disturbance' approach would reduce the costs of active management. Thirdly, a longterm experimental project in protected areas, like the Swedish Oak Project, is possible for a surmountable cost, but very rare due to seeming lack of interest and short-term incentives in the academic funding system. In this situation, evidence-based databases are one way ahead (e.g. Conservation Evidence 2018) to increase the sway of empirical evidence in nature conservation; alternatively, already on-going monitoring may be linked to experimental management, to ensure that the value of this long-term work is fully utilised (see Nichols and Williams 2006; Götmark et al. 2015).

Acknowledgements We thank Niklas Franc for providing us with his data, Olof Persson for help with fieldwork, the foundation 'Stiftelsen Oscar och Lili Lamms Minne' for generous support, and the reviewer and associate editor for helpful comments.

Open Access This article is distributed under the terms of the Creative Commons Attribution 4.0 International License (http://creativecommons.org/licenses/by/4.0/), which permits unrestricted use, distribution, and reproduction in any medium, provided you give appropriate credit to the original author(s) and the source, provide a link to the Creative Commons license, and indicate if changes were made. 


\section{References}

Alexander KN (1999) Should deadwood be left in sun or shade? Br Wildl 10:342

Anderson MJ (2001) A new method for non-parametric multivariate analysis of variance. Austral Ecol 26:32-46

Anderson MJ, Gorley RN, Clarke KR (2008) PERMANOVA + for PRIMER: guide to software and statistical methods. PRIMER-E, Plymouth

Bates D, Mächler M, Bolker B, Walker S (2015) Fitting linear mixed-effects models using lme. J Stat Softw 67:1-48

Bouget C (2005) Short-term effect of windstorm disturbance on saproxylic beetles in broadleaved temperate forests: part I: do environmental changes induce a gap effect? For Ecol Manage 216:1-14. https://doi.org/10.1016/j.foreco.2005.05.037

Bouget C, Brin A, Brustel H (2011) Exploring the "last biotic frontier": are temperate forest canopies special for saproxylic beetles? For Ecol Manage 261:211-220. https://doi.org/10.1016/j.forec o.2010.10.007

Bouget C, Larrieu L, Nusillard B, Parmain G (2013) In search of the best local habitat drivers for saproxylic beetle diversity in temperate deciduous forests. Biodivers Conserv 22:2111-2130. https:// doi.org/10.1007/s10531-013-0531-3

Bouget C, Larrieu L, Brin A (2014) Key features for saproxylic beetle diversity derived from rapid habitat assessment in temperate forests. Ecol Indic 36:656-664. https://doi.org/10.1016/j.ecoli nd.2013.09.031

Brin A, Brustel H, Jactel H (2009) Species variables or environmental variables as indicators of forest biodiversity: a case study using saproxylic beetles in Maritime pine plantations. Ann For Sci 66:306. https://doi.org/10.1051/forest/2009009

Brudvig LA, Blunck HM, Asbjornsen H, Mateos-Remigio VS, Wagner SA, Randall JA (2011) Influences of woody encroachment and restoration thinning on overstory savanna oak tree growth rates. For Ecol Manage 262:1409-1416. https://doi.org/10.1016/j.foreco.2011.06.038

Cálix M, Alexander KNA, Nieto A, Dodelin B, Soldati F, Telnov D, Vazquez-Albalate X, Aleksandrowicz O, Audisio P, Istrate P, Jansson N, Legakis A, Liberto A, Makris C, Merkl O, Mugerwa Pettersson R, Schlaghamersky J, Bologna MA, Brustel H, Buse J, Novák V, Purchart L (2018) European red list of saproxylic beetles. IUCN, Brussels

Chen H (2017) VennDiagram: generate high-resolution venn and Euler plots. R package version 1.6.18. https:/CRAN.R-project.org/package=VennDiagram

Clarke KR, Gorley RN, Somerfield PJ, Warwick RM (2014) Change in marine communities: an approach to statistical analysis and interpretation, 3rd edn. PRIMER-E, Plymouth

Colwell RK (2013) EstimateS: statistical estimation of species richness and shared species from samples. Version 9. http://purl.oclc.org/estimates

Colwell RK, Chao A, Gotelli NJ, Lin SY, Mao CX, Chazdon RL, Longino JT (2012) Models and estimators linking individual-based and sample-based rarefaction, extrapolation and comparison of assemblages. J Plant Ecol 5:3-21. https://doi.org/10.1093/jpe/rtr044

Conservation Evidence (2018). https://www.conservationevidence.com

Cook RD (1977) Detection of influential observation in linear regression. Technometrics 19:15-18. https ://doi.org/10.2307/1268249

Cook CN, Hockings M, Carter RW (2010) Conservation in the dark? The information used to support management decisions. Front Ecol Environ 8:181-186. https://doi.org/10.1890/090020

Dahlberg A, Stokland JN (2004) Vedlevande arters krav på substrat-sammanställning och analys av 3600 arter. Skogsstyrelsen, Jönköping

Davies ZG, Tyler C, Stewart GB, Pullin AS (2008) Are current management recommendations for saproxylic invertebrates effective? A systematic review. Biodivers Conserv 17:209-234. https://doi. org/10.1007/s 10531-007-9242-y

Franc N, Götmark F (2008) Openness in management: hands-off vs partial cutting in conservation forests, and the response of beetles. Biol Conserv 141:2310-2321. https://doi.org/10.1016/j.bioco n.2008.06.023

Franc N, Götmark F, Økland B, Nordén B, Paltto H (2007) Factors and scales potentially important for saproxylic beetles in temperate mixed oak forest. Biol Conserv 135:86-98. https://doi. org/10.1016/j.biocon.2006.09.021

Geological Survey of Sweden (2018) SGUs Kartvisare. https://apps.sgu.se/kartvisare. Accessed 9 March 2018 
Gotelli NJ, Colwell RK (2001) Quantifying biodiversity: procedures and pitfalls in the measurement and comparison of species richness. Ecol Lett 4:379-391. https://doi.org/10.104 6/j.1461-0248.2001.00230.x

Götmark F (2007) Careful partial harvesting in conservation stands and retention of large oaks favour oak regeneration. Biol Conserv 140:349-358. https://doi.org/10.1016/j.biocon.2007.08.018

Götmark F (2013) Habitat management alternatives for conservation forests in the temperate zone: review, synthesis, and implications. For Ecol Manage 306:292-307. https://doi.org/10.1016/j.forec o.2013.06.014

Götmark F, Paltto H, Nordén B, Götmark E (2005) Evaluating partial cutting in broadleaved temperate forest under strong experimental control: short-term effects on herbaceous plants. For Ecol Manage 214:124-141. https://doi.org/10.1016/j.foreco.2005.03.052

Götmark F, Kirby K, Usher MB (2015) Strict reserves, IUCN classification, and the use of reserves for scientific research: a comment on Schultze et al. (2014). Biodivers Conserv 24:3621-3625. https://doi. org/10.1007/s10531-015-1011-8

Grove SJ (2002) Saproxylic insect ecology and the sustainable management of forests. Annu Rev Ecol Syst 33:1-23. https://doi.org/10.1146/annurev.ecolsys.33.010802.150507

Hammond HE, Langor DW, Spence JR (2001) Early colonization of Populus wood by saproxylic beetles (Coleoptera). Can J For Res 31:1175-1183. https://doi.org/10.1139/x01-057

Hjältén J, Stenbacka F, Pettersson RB, Gibb H, Johansson T, Danell K, Ball JP, Hilszczański J (2012) Micro and macro-habitat associations in saproxylic beetles: implications for biodiversity management. PLoS ONE 7:e41100. https://doi.org/10.1371/journal.pone.0041100

Hope RM (2013) Rmisc: Ryan miscellaneous. R package version 1.5. https://CRAN.R-project.org/packa ge $=$ Rmisc

Jonsell M (2012) Old park trees as habitat for saproxylic beetle species. Biodivers Conserv 21:619-642. https://doi.org/10.1007/s10531-011-0203-0

Jonsell M, Weslien J, Ehnström B (1998) Substrate requirements of red-listed saproxylic invertebrates in Sweden. Biodivers Conserv 7:749-764. https://doi.org/10.1023/A:1008888319031

Jonsell M, Nittérus K, Stighäll K (2004) Saproxylic beetles in natural and man-made deciduous high stumps retained for conservation. Biol Conserv 118:163-173. https://doi.org/10.1016/j.biocon.2003.08.017

Komonen A, Kuntsi S, Toivanen T, Kotiaho JS (2014) Fast but ephemeral effects of ecological restoration on forest beetle community. Biodivers Conserv 23:1485-1507. https://doi.org/10.1007/s1053 1-014-0678-6

Kuznetsova A, Brockhoff PB, Christensen RH (2017) lmerTest package: tests in linear mixed effects models. J Stat Softw 82:1-26

Lassauce A, Paillet Y, Jactel H, Bouget C (2011) Deadwood as a surrogate for forest biodiversity: metaanalysis of correlations between deadwood volume and species richness of saproxylic organisms. Ecol Indic 11:1027-1039. https://doi.org/10.1016/j.ecolind.2011.02.004

Lassauce A, Lieutier F, Bouget C (2012) Woodfuel harvesting and biodiversity conservation in temperate forests: effects of logging residue characteristics on saproxylic beetle assemblages. Biol Conserv 147:204-212. https://doi.org/10.1016/j.biocon.2012.01.001

Leonardsson J (2015) Management of oak-rich mixed forests: conservation-oriented thinning and response of trees and shrubs. Dissertation, University of Gothenburg. https://gupea.ub.gu.se/handle/2077/40007

Leonardsson J, Löf M, Götmark F (2015) Exclosures can favour natural regeneration of oak after conservation-oriented thinning in mixed forests in Sweden: a 10-year study. For Ecol Manage 354:1-9. https:// doi.org/10.1016/j.foreco.2015.07.004

Lindhe A, Lindelöw A, Åsenblad N (2005) Saproxylic beetles in standing dead wood density in relation to substrate sun-exposure and diameter. Biodivers Conserv 14:3033-3053. https://doi.org/10.1007/s1053 1-004-0314-y

Lindroth CH (1961) Svensk insektfauna 9-Skalbaggar. Coleoptera-Sandjägare och jordlöpare-Fam. Carabidae. Entomologiska Föreningen i Stockholm, Stockholm

Luke SG (2017) Evaluating significance in linear mixed-effects models in R. Behav Res 49:1494-1502. https://doi.org/10.3758/s13428-016-0809-y

MacLean DA, Dracup E, Gandiaga F, Haughian SR, MacKay A, Nadeau P, Omari K, Adams G, Frego KA, Keppie D, Moreau G (2015) Experimental manipulation of habitat structures in intensively managed spruce plantations to increase their value for biodiversity conservation. For Chron 91:161-175. https:// doi.org/10.5558/tfc2015-027

Martikainen P, Siitonen J, Punttila P, Kaila L, Rauh J (2000) Species richness of Coleoptera in mature managed and old-growth boreal forests in southern Finland. Biol Conserv 94:199-209. https://doi. org/10.1016/S0006-3207(99)00175-5 
McCabe DJ, Gotelli NJ (2000) Effects of disturbance frequency, intensity, and area on assemblages of stream macroinvertebrates. Oecologia 124:270-279. https://doi.org/10.1007/s004420000369

Morales-Hidalgo D, Oswalt SN, Somanathan E (2015) Status and trends in global primary forest, protected areas, and areas designated for conservation of biodiversity from the Global Forest Resources Assessment 2015. For Ecol Manage 352:68-77. https://doi.org/10.1016/j.foreco.2015.06.011

Morey RD (2008) Confidence intervals from normalized data: a correction to Cousineau (2005). Tutor Quant Methods Psychol 4:61-64. https://doi.org/10.20982/tqmp.04.2.p061

Newell P, King S (2009) Relative abundance and species richness of cerambycid beetles in partial cut and uncut bottomland hardwood forests. Can J For Res 39:2100-2108. https://doi.org/10.1139/ X09-105

Nichols JD, Williams BK (2006) Monitoring for conservation. Trends Ecol Evol 21:668-673. https:// doi.org/10.1016/j.tree.2006.08.007

Nieuwenhuis R, te Grotenhuis HF, Pelzer BJ (2012) influence.ME: tools for detecting influential data in mixed effects models. R J 4:38-47

Nordén B, Götmark F, Tönnberg M, Ryberg M (2004) Dead wood in semi-natural temperate broadleaved woodland: contribution of coarse and fine dead wood, attached dead wood and stumps. For Ecol Manage 194:235-248. https://doi.org/10.1016/j.foreco.2004.02.043

Nordén B, Paltto H, Claesson C, Götmark F (2012) Partial cutting can enhance epiphyte conservation in temperate oak-rich forests. For Ecol Manage 270:35-44. https://doi.org/10.1016/j.foreco.2012.01.014

Økland B, Götmark F, Nordén B (2008) Oak woodland restoration: testing the effects on biodiversity of mycetophilids in southern Sweden. Biodivers Conserv 17:2599-2616. https://doi.org/10.1007/ s10531-008-9325-4

Paltto H, Nordén B, Götmark F, Franc N (2006) At which spatial and temporal scales does landscape context affect local density of Red Data Book and Indicator species? Biol Conserv 133:442-454. https://doi.org/10.1016/j.biocon.2006.07.006

Parmain G, Bouget C, Müller J, Horak J, Gossner MM, Lachat T, Isacsson G (2015) Can rove beetles (Staphylinidae) be excluded in studies focusing on saproxylic beetles in central European beech forests? Bull Entomol Res 105:101-109. https://doi.org/10.1017/S0007485314000741

Peterken GF (2001) Natural woodland: ecology and conservation in northern temperate regions. University of Cambridge, Cambridge

Pullin AS, Knight TM, Stone DA, Charman K (2004) Do conservation managers use scientific evidence to support their decision-making? Biol Conserv 119:245-252. https://doi.org/10.1016/j.bioco n.2003.11.007

R Core Team (2017) R: a language and environment for statistical computing. R Foundation for Statistical Computing. https://www.R-project.org

Rancka B, von Proschwitz T, Hylander K, Götmark F (2015) Conservation thinning in secondary forest: negative but mild effect on land molluscs in closed-canopy mixed oak forest in Sweden. PLoS ONE 10:e0120085. https://doi.org/10.1371/journal.pone.0120085

Ranius T, Jansson N (2000) The influence of forest regrowth, original canopy cover and tree size on saproxylic beetles associated with old oaks. Biol Conserv 95:85-94. https://doi.org/10.1016/S0006 $-3207(00) 00007-0$

Ranius T, Eliasson P, Johansson P (2008) Large-scale occurrence patterns of red-listed lichens and fungi on old oaks are influenced both by current and historical habitat density. Biodivers Conserv 17:2371-2381. https://doi.org/10.1007/s10531-008-9387-3

Schneider CA, Rasband WS, Eliceiri KW (2012) NIH Image to ImageJ: 25 years of image analysis. Nat Methods 9:671. https://doi.org/10.1038/nmeth.2089

Sebek P, Bace R, Bartos M, Benes J, Chlumska Z, Dolezal J, Dvorsky M, Kovar J, Machac O, Mikatova B, Perlik M (2015) Does a minimal intervention approach threaten the biodiversity of protected areas? A multi-taxa short-term response to intervention in temperate oak-dominated forests. For Ecol Manage 358:80-89. https://doi.org/10.1016/j.foreco.2015.09.008

Similä M, Kouki J, Martikainen P, Uotila A (2002) Conservation of beetles in boreal pine forests: the effects of forest age and naturalness on species assemblages. Biol Conserv 106:19-27. https://doi. org/10.1016/S0006-3207(01)00225-7

Stokland S, Siitonen J, Jonsson BG (2012) Biodiversity in dead wood. Cambridge University Press, Cambridge

Svedrup-Thygeson A, Ims RA (2002) The effect of forest clearcutting in Norway on the community of saproxylic beetles on aspen. Biol Conserv 106:347-357. https://doi.org/10.1016/S0006-3207(01)00261-0

Sverdrup-Thygeson A, Skarpaas O, Ødegaard F (2010) Hollow oaks and beetle conservation: the significance of the surroundings. Biodivers Conserv 19:837-852. https://doi.org/10.1007/s10531-009-9739-7 
Swedish Meteorological and Hydrological Institute (2014). Klimatdata. https://www.smhi.se/klimatdata . Accessed 2 February 2014

The Swedish Species Information Centre (2000) Rödlistade arter i Sverige 2000. Swedish University of Agricultural Sciences, Uppsala

The Swedish Species Information Centre (2005) Rödlistade arter i Sverige 2005. Swedish University of Agricultural Sciences, Uppsala

The Swedish Species Information Centre (2010) Rödlistade arter i Sverige 2010. Swedish University of Agricultural Sciences, Uppsala

The Swedish Species Information Centre (2018). Artfakta. Swedish University of Agricultural Sciences. http://artfakta.artdatabanken.se. Accessed 8 January 2018

Tilman D (1987) Ecological experimentation: strengths and conceptual problems. In: Likens GE (ed) Longterm studies in ecology. Springer, New York, pp 136-157

Timonen J, Siitonen J, Gustafsson L, Kotiaho JS, Stokland JN, Sverdrup-Thygeson A, Mönkkönen M (2010) Woodland key habitats in northern Europe: concepts, inventory and protection. Scand J For Res 25:309-324. https://doi.org/10.1080/02827581.2010.497160

Toivanen T, Kotiaho JS (2010) The preferences of saproxylic beetle species for different dead wood types created in forest restoration treatments. Can J For Res 40:445-464. https://doi.org/10.1139/X09-205

TSOP, The Swedish Oak Project (2018). https://bioenv.gu.se/english/research/main-research-areas/evolu tionary-ecology-conservation/oakproject

Tyler M (2008) British oaks: a concise guide. Crowood Press, Marlborough

Vandekerkhove K, Thomaes A, Crèvecoeur L, De Keersmaeker L, Leyman A, Köhler F (2016) Saproxylic beetles in non-intervention and coppice-with-standards restoration management in Meerdaal forest (Belgium): an exploratory analysis. iForest 9:536-545. https://doi.org/10.3832/ifor1841-009

Vodka S, Konvicka M, Cizek L (2009) Habitat preferences of oak-feeding xylophagous beetles in a temperate woodland: implications for forest history and management. J Insect Conserv 13:553-562. https:// doi.org/10.1007/s10841-008-9202-1

Warriner MD, Nebeker TE, Leininger TD, Meadows JS (2002) The effects of thinning on beetles (Coleoptera: Carabidae, Cerambycidae) in bottomland hardwood forests. Gen. Tech. Rep. SRS-48. U.S. Department of Agriculture, Forest Service, Southern Research Station, Asheville. pp 569-573. https:// www.fs.usda.gov/treesearch/pubs/3106

Wickham H (2009) ggplot2: elegant graphics for data analysis. Springer-Verlag, New York

Widerberg MK, Ranius T, Drobyshev I, Nilsson U, Lindbladh M (2012) Increased openness around retained oaks increases species richness of saproxylic beetles. Biodiv Conserv 21:3035-3059. https://doi. org/10.1007/s10531-012-0353-8

Widerberg MK, Ranius T, Drobyshev I, Lindbladh M (2018) Oaks retained in production spruce forests help maintain saproxylic beetle diversity in southern Scandinavian landscapes. For Ecol Manage 417:257264. https://doi.org/10.1016/j.foreco.2018.02.048

Wikars LO, Sahlin E, Ranius T (2005) A comparison of three methods to estimate species richness of saproxylic beetles (Coleoptera) in logs and high stumps of Norway spruce. Can Entomol 137:304-324. https://doi.org/10.4039/n04-104

Zuur AF, Ieno EN, Elphick CS (2010) A protocol for data exploration to avoid common statistical problems. Methods Ecol Evol 1:3-14. https://doi.org/10.1111/j.2041-210X.2009.00001.x

Publisher's Note Springer Nature remains neutral with regard to jurisdictional claims in published maps and institutional affiliations. 